\title{
VARIABILIDADE GENÉTICA EM UM ENSAIO DE PROGÊNIES DE ERVA- MATE (Ilex paraguariensis St.Hil.)
}

\author{
GENETIC VARIABILITY IN A TRIAL OF ERVA-MATE \\ (Ilex paraguariensis St.Hil.) PROGENIES
}

\section{Mario Angelo Vidor ${ }^{1}$ César Pérez Ruiz ${ }^{2}$ Santiago Vázquez Moreno ${ }^{3}$ Paulo Alfonso Floss ${ }^{4}$}

\section{RESUMO}

A Epagri (Empresa de Pesquisa Agropecuária e Extensão Rural de Santa Catarina S.A) possui uma das maiores coleções brasileiras de erva-mate (Ilex paraguariensis St.Hil.). A partir de ensaios agronômicos preliminares, apresentaram destaque as procedências Barão de Cotegipe e Água Doce. O objetivo deste trabalho foi o de caracterizar geneticamente a variabilidade existente nos germoplasmas oriundos destas procedências. A técnica utilizada foi a de marcadores moleculares para amplificar o DNA, do tipo RAPD (Random Amplified Polymorphic DNA). Os resultados indicaram não ser possivel diferenciar geneticamente as procedências entre si. Em função da distância genética, foi formado um grupo com quatro materiais ou germoplasmas e outro com os demais. Os diferentes materiais das duas procedências estudadas apresentaram similaridade superior a $80 \%$ entre eles.

Palavras-chave: Ilex paraguariensis, variabilidade genética, marcadores moleculares, DNA, RAPD, PCR.

\section{SUMMARY}

The Santa Catarina State Agricultural Research and Extension Organization - Epagri SA, owns one of the largest Brazilian colletions of erva-mate (Ilex paraguariensis St.Hil.). Preliminary agronomic trials identified two promissing erva-mate materials named as Barão de Cotegipe and Água Doce. This study had the objective of characterizing genetically the existing variability in the two mentioned materials. A molecular marker technique was used to amplify the DNA, RAPD (Random Amplified Polimorfic DNA). The results showed no genetic difference between the two materials. Also, due to the genetic distance between them, the different materials from both studied origins showed genetic similarity of up to $80 \%$.
Key words: Ilex paraguariensis, genetic variability, molecular markers, DNA, RAPD, PCR.

\section{INTRODUÇÃO}

A erva-mate (Ilex paraguariensis St.Hil.) é uma espécie arbórea endêmica do Continente Americano, de distribuição natural entre as latitudes de $21^{\circ}$ e $30^{\circ} \mathrm{S}$ e longitude entre $48^{\circ} 38^{\prime}$ e $56^{\circ} 10^{\prime} \mathrm{W}$, ocupando $540.000 \mathrm{~km}^{2}$, dos quais, $450.000 \mathrm{~km}^{2}$ são no Brasil, nos estados do Rio Grande do Sul, Santa Catarina, Paraná e sul do Mato Grosso do Sul (DA CROCE et al., 1994).

Há algumas décadas, a erva-mate aparece como uma das espécies arbóreas naturais de maior importância econômica para o sul do Brasil, nordeste da Argentina e todo Paraguai. A importância sócioeconômica desta planta é significativa, principalmente pelo fato de ser uma das espécies que sofre pouco com as oscilações do clima, em relação com os cultivos agrícolas em geral. Por isso, passou a ser uma espécie de grande importância na fixação do homem ao campo. Através da industrialização de suas folhas e ramos, obtém-se o produto industrializado destinado à preparação de uma bebida tônica e estimulante, conhecida como chá de mate, chimarrão ou tererê.

\footnotetext{
${ }^{1}$ Engenheiro Agrônomo, PhD, Pesquisador da Epagri Empresa de Pesquisa Agropecuária e Extensão Rural de Santa Catarina (Epagri), Estação Experimental de Lages, CP 181, 88502-970, Lages/SC. E-mail: vidor@epagri.rct-sc.br. Autor para correspondência.

${ }^{2}$ Biólogo, PhD, Professor e Chefe do Departamento de Biología Vegetal da Escuela Tecnica Superior de Ingenieros Agrónomos da Universidad Politécnica de Madrid/España.

${ }^{3}$ Engenheiro Agrônomo, PhD, Professor do Departamento de Biología Vegetal da Escuela Tecnica Superior de Ingenieros Agrónomos da Universidad Politécnica de Madrid, España.

${ }^{4}$ Engenheiro Florestal, MSc., Pesquisador da Epagri/SC, CPPP Chapecó.
} 
Entre suas qualidades medicinais e nutricionais (em especial, por seu alto conteúdo em vitamina A), apresenta efeito diurético, estimulante, sendo muito útil em tratamentos de dieta e desintoxicação do organismo. Ainda que seu principal consumo seja como bebida tônica, começou-se a utilizá-la também, para outros fins, como a produção de desodorantes e corantes.

A Empresa de Pesquisa Agropecuária e Extensão Rural de Santa Catarina (EPAGRI), através do Centro de Pesquisa para Pequenas Propriedades (CPPP) de Chapecó, SC, possui uma das maiores coleções brasileiras de erva-mate, com plantas de várias procedências, todas de origem natural e com grande variabilidade fenotípica. A partir de ensaios preliminares qualitativos $\mathrm{e}$ quantitativos, nos quais foram analisadas altura de planta, diâmetro de copa, densidade foliar, sobrevivência das plantas, comportamento de rebrote e identificação de plantas femininas e masculinas, seis procedências - Água Doce, Concórdia, Barão de Cotegipe, Passo Fundo, Ilópolis y Venâncio Aires - (populações naturais) estudadas se destacaram para o conjunto de caracteres avaliados (FLOSS, 1994). Com a utilização de sementes destas procedências, é possível obter um ganho genético superior aos 5\% (DA CROCE $\boldsymbol{e t}$ al., 1994), o qual pode ser ainda maior nas procedências Barão de Cotegipe e Água Doce. Em 1996, foram coletadas progênies destas duas procedências - que já haviam apresentado melhor rendimento em ensaio anterior, plantas livres de doenças e pragas, com alta densidade folhar e grande produção de frutos - para realizar ensaios em apoio a um programa de melhoramento vegetal em erva-mate (FLOSS, 1997). De cada procedência, foram coletadas 28 progênies, sendo que o número final de progênies foi menor porque algumas não germinaram.

O objetivo deste estudo foi o de caracterizar a variabilidade existente no germoplasma das procedências de erva-mate Barão de Cotegipe e Água Doce, definindo padrões genéticos, determinando a variabilidade genética existente entre os materiais e reduzindo o tempo necessário na execução do teste de progênie, uma vez que se pode conhecer geneticamente as plantas antes que se tornem adultas. Assim, elas podem se constituir em fonte de material de grande valor e geneticamente estável para a produção de cultivares. Para isto, foram utilizados marcadores moleculares que amplificam o DNA, de tipo RAPD (Random Amplified Polymorphic DNA).

\section{MATERIAL E MÉTODOS}

\section{Material vegetal}

O material vegetal estudado, numa primeira etapa, veio da coleta de plantas de erva-mate (Ilex paraguariensis St.Hil.) a campo, em distintas zonas do sul do Brasil, as quais se destacavam por suas características fenotípicas. Estes materiais foram cultivados no CPPP da EPAGRI em Chapecó/SC e deles foram escolhidos, mais uma vez, os melhores quanto à características fenotípicas, que serviram de fonte vegetal para este trabalho.

De cada planta, foram colhidas as folhas mais jovens para realizar as extrações de DNA, uma vez que as folhas mais velhas produzem interferências na reação, devido à quantidade de polissacarídeos e fenóis que possuem. Foi usado o DNA genômico para as reações.

As amostras das plantas foram numeradas de 1 a 25 para a procedência Barão de Cotegipe e de 26 a 38 para Água Doce.

\section{Extração e isolamento do DNA}

O protocolo de extração de DNA utilizado (VIDOR \& BELÓ, 2000; FERREIRA \& GRATTAPAGLIA, 1995), e que se caracteriza por utilizar o detergente catiônico CTAB (cationic hexadecyl trimethyl ammonium bromide) no tampão de extração, apresenta cinco etapas. $\mathrm{Na}$ primeira, macera-se o material vegetal com ajuda de um almofariz e nitrogênio líquido. Na segunda etapa, o material vegetal é resuspenso num tampão de extração com um detergente, antioxidante, EDTA e agente tamponante. $\mathrm{Na}$ terceira etapa, esta suspensão é submetida a uma extração com um solvente orgânico, clorofórmio-álcool isoamílico. Na quarta etapa, é adicionado álcool (etanol) na fase aquosa para precipitação do DNA. Na quinta, o precipitado DNA/RNA é resuspenso em um tampão Tris-EDTA com RNAse, para degradar o RNA ficando, somente, o DNA genômico desejado.

\section{Condições da reação}

As reações continham uma unidade de Taq DNA polymerase (Biotools, Biotechnological \& Medical Laboratories, Madrid, Spain); 0,2 $\mu \mathrm{M}$ primer (British Columbia) (primers BC 512, 515, 518, 519, 521, 523, 542, 543, 546, 551); 0,1mM dNTP ( dNTP Master Mix, Ecogen srl, Ptge Dos de Maig, Barcelona, Spain); 75mM TrisHCl ( $\mathrm{pH}=9,0)$, $2 \mathrm{mM} \mathrm{MgCl}_{2}, 50 \mathrm{mM} \mathrm{KC} \ell, 20 \mathrm{mM} \quad\left(\mathrm{NH}_{4}\right)_{2} \mathrm{SO}_{4}$, 0,001\% BSA, concentração 1 x (Biottols buffer); água esterilizada e 5,0ng/ $\mu \ell$ DNA em $25 \mu \ell$ de volume total. O PCR foi corrido usando um termociclador MJ Research, Inc, PTC-100 Programmable Thermal Controller (Watertown, Mass., USA) com ciclos térmicos programados de $2 \mathrm{~min}$ a $94^{\circ} \mathrm{C}$, seguido de 40 ciclos de $1 \mathrm{~min}$ a $92^{\circ} \mathrm{C}$, $1 \mathrm{~min}$ a $35^{\circ} \mathrm{C}$ e $2 \min$ a $72^{\circ} \mathrm{C}$, seguidos de $5 \mathrm{~min}$ a $72^{\circ} \mathrm{C}$. Foram feitos quarenta ciclos que duraram 
aproximadamente 5h. Completada a reação, as misturas foram mantidas em temperatura ambiente até análise em gel TBE de agarose a 1,5\%, corado com brometo de etídio e fotografado com filme de câmara Polaroid. Todos os experimentos foram duplicados, usando-se uma nova extração de DNA de $60 \%$ das novas amostras de folhas. Bandas não reproduzidas foram rejeitadas. A análise estatística usou o programa NTSYS.

\section{RESULTADOS E DISCUSSÃO}

Os resultados apresentados no dendograma da figura 1 , no que diz respeito a variabilidade existente entre os diferentes materiais ou germoplasmas das duas procedências de erva-mate estudadas, apontam para uma similaridade em nível de $80 \%$ para todos os materiais. Não foi possível distinguir, claramente, grupos formados distintamente pelas procedências Barão de Cotegipe (materiais de 1 a 25) e Água Doce (26 a 38). No entanto, parece haver maior aproximação a um nível superior a $89 \%$ para os materiais de Água Doce. Os dados de variação genética entre as duas populações são semelhantes aos obtidos por GAUER \& CAVALLI-MOLINA, 2000), nos quais a variação entre as quatro populações estudadas foi pequena. Já para estes autores, a variação obtida em seu trabalho com erva-mate em plantas dentro da mesma população foi grande, sendo que os mesmos atribuem este fato, provavelmente, ao resultado das características da história da erva-mate. HAMRICK (1979) já havia demonstrado uma associação positiva entre as características de fecundação e ciclo de vida desta espécie e a variação genética. Para HAMRICK \& GODT, 1989), o curso da história da erva-mate pode afetar a estrutura ge-

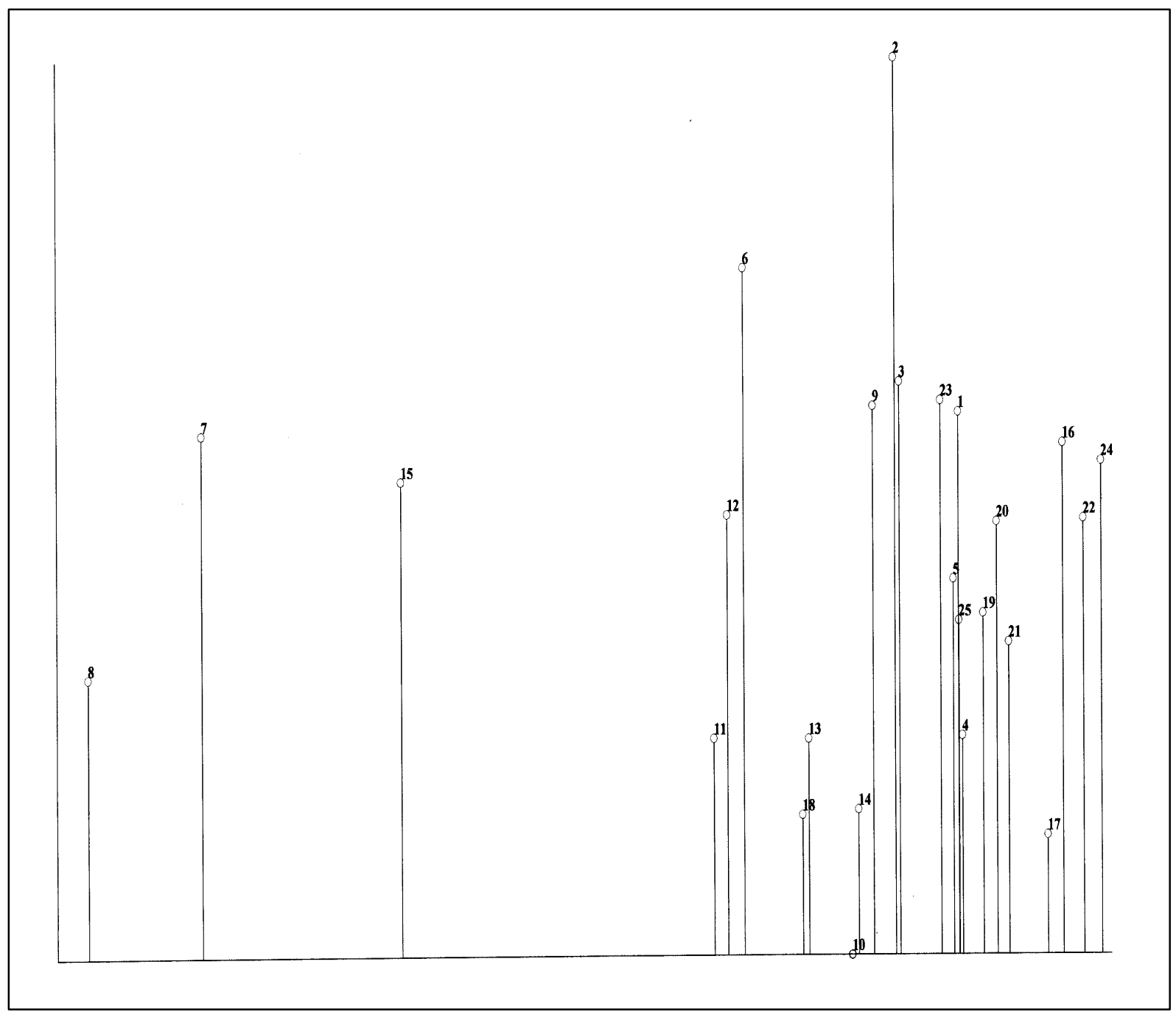

Figura 1 - Dendograma resultado da análise RAPDs apresentado as relações existentes entre 38 acessos de erva-mate. 
nética das populações de plantas, influenciando na variabilidade genética.

Pode-se afirmar que existe similaridade a nível de 95\% (ligeiramente superior ou inferior) entre os materiais de número 20 e $22 ; 6$ e $18 ; 21$ e 23; e o material 13 com os materiais 8 e 28 , que são idênticos; similaridade a nível de $96 \%$ (ligeiramente superior ou inferior) entre os materiais 16 e 30; 15 e 17; similaridade a nível de $97 \%$ (ligeiramente superior ou inferior) entre os materiais 1 e $11 ; 24 \mathrm{e}$ $25 ; 12$ e $33 ; 27$ e 31 ; e a nível de $98,5 \%$, entre os materiais 32 e 34 .

Ainda pode-se afirmar entre os materiais já citados que, a nível de semelhança superior a $90 \%$, estão os materiais $1,6,11,12,15,16,17,18,20,21$, $22,23,24,25,27,30,31,32,33,34$, obviamente com outros materiais aqui não mencionados por não apresentarem, par a par, maior similaridade que a já descrita.
Dois grupos maiores se formam a um nível de semelhança de $81 \%$, sendo que um deles é formado pelos materiais $5,8,13$ e 28 e, o outro grupo, pelos demais. A figura 2 apresenta os dados em uma forma de dimensão espacial.

De uma maneira geral, com este trabalho conseguiram-se definir padrões genéticos para a erva-mate. A técnica de marcadores moleculares ficou definida. Por tratar-se de estudos realizados com procedências da mesma espécie vegetal, os resultados obtidos quanto à baixa variabilidade genética já eram esperados. Talvez a formação dos grupos quanto à distância genética pudessem ser distintos, formando-se grupos de distância genética entre as duas procedências. Contudo, os baixos índices de variabilidade obtidos foram considerados normais.

GAUER \& CAVALLI-MOLINA (2000) também afirmam que baixa divergência genética entre populações já foi obtido para outras espécies.

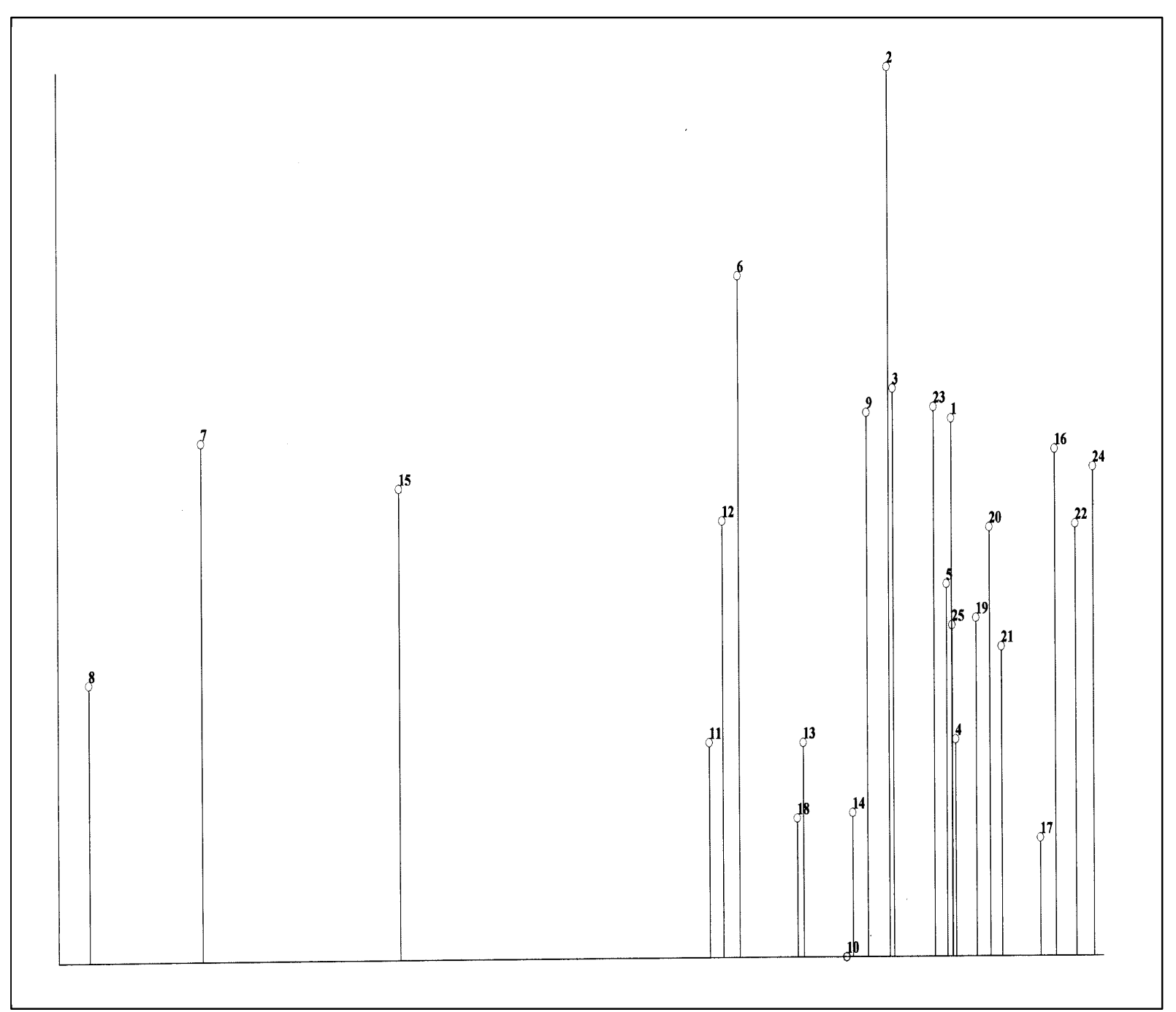

Figura 2 - Representação espacial de 38 acessos de erva-mate estudados. 
Esta conclusão é sustentada pelo fato de a maioria das bandas serem comuns a todas as populações e as bandas específicas ocorrerem à baixa freqüência, como observado neste estudo e também com outras espécies (WANG et al., 1996). No entanto, os dados deste estudo contrastam, até certo ponto, com os obtidos por GAUER \& CAVALLI-MOLINA (2000), nos quais os mesmos obtiveram diversidade genética de $85 \%$ na população e de $15 \%$ entre populações. Para eles, a maior variação ocorreu dentro da população, ainda que tenham sido registrados grupos de plantas em cada população nos dendogramas.

Por fim, estes resultados auxiliarão muito os melhoristas na hora de selecionar com que características e com que materiais irão trabalhar. Eles permitirão reduzir o tempo necessário na execução do teste de progênie, e possibilitarão agregar o maior número possível de caracteres desejáveis ao novo material selecionado.

\section{CONCLUSÃO}

Os diferentes materiais das procedências Barão de Cotegipe e Água Doce apresentaram acentuada similaridade entre eles. Não foi possível diferenciar geneticamente as duas procedências entre si. O grupo formado pelos materiais ou germoplasmas de números 5, 8, 13 (Barão de Cotegipe) e 28 (Água Doce), se destacou dos demais materiais a um nível de similaridade superior a $80 \%$.

\section{AGRADECIMENTOS}

Este trabalho só pôde ser realizado com o apoio financeiro da CAPES, da EPAGRI, e do Departamento de Biología Vegetal da Escuela Tecnica Superior de Ingenieros Agrónomos da Universidad Politecnica de Madrid / Espanha, além do apoio de colegas. A todos, nossos agradecimentos.

\section{REFERÊNCIAS BIBLIOGRÁFICAS}

DA CROCE,D.M.; HIGA,A.R.; FLOSS,P.A. Escolha de fontes de sementes de erva-mate (Ilex paraguariensis St.Hil.) para Santa Catarina. Florianópolis : EPAGRI, 1994. 23p. (EPAGRI. Boletim Técnico, 69).

FERREIRA,M.E.; GRATAPAGLIA,D. Introdução ao uso de marcadores RAPD e RFLP em análise genética. Brasília : EMBRAPA-CENARGEN, 1995. 221p.

FLOSS,P.A. Programa de melhoramento genético da ervamate na EPAGRI. In: CONGRESSO SUL-AMERICANO DA ERVA-MATE E,1; REUNIÃO TÉCNICA DO CONE SUL SOBRE A CULTURA DA ERVA-MATE2, 1997. Anais... Curitiba : EMBRAPA, 1997. p.279-284. (Documentos 33).

FLOSS,P.A. Variaçoes genéticas entre populaçoes naturais de Ilex paraguariensis St.Hil. (erva-mate) avaliados em Chapecó, SC e Três Barras, SC. Piracicaba, 1994. 94p. Dissertaçao (Mestrado em Engenharia Florestal) - USP, 1994.

GAUER,L.; CAVALLI-MOLINA,S. Genetic variation in natural populations of maté (Ilex paraguariensis A. St.Hil., Aquifoliaceae) using RAPD markers. Heredity, v.84, p.647656,2000

HAMRICK,J.L. Gentic variation and longevity. In: SOLBRIG,O.T., JAIN,S., JOHNSON,G.B., et al. (eds). Topics in Plant Population Biology. New York : Columbia University, 1979. p.84-113.

HAMRICK,J.L.; GODT,M.T. Allozyme diversity in plant species. In: BROWN,A.D.H., CLEGG,M.T., KAHLER,A.L. et al. (eds). Plant Population Genetics, Breeding, and Genetic Resources. Sunderland, MA : Sinauer Associates, 1989. p.43-63.

VIDOR,M.A.; BELÓ,A. Protocolo para extração de DNA de erva-mate (Ilex paraguariensis St.Hil.). In: CONGRESSO DE BIOTECNOLOGIA VEGETAL, 2000, Evora, Portugal.. Anais... Evora, Portugal : Universidade de Evora, 2000.

WANG,C.T.; WANG,W.Y.; CHIANG,C.H.; et al. Low genetic variation in Amentotaxus formosana $\mathrm{Li}$ revealed by isozyme analysis and random amplified polymorphic DNA markers. Heredity, v.77, p.388-395, 1996. 